\title{
Stabilizacja potyliczno-szyjna u chorego w przebiegu szpiczaka. Modyfikacja metody operacyjnej. Nota techniczna
}

\section{Occipito-cervical fixation in plasmocytoma. Method modification. Technical report}

\author{
Jarosław Andrychowski ${ }^{1,2}$, Zbigniew Czernicki, ${ }^{1,2}$, Piotr Jasielski ${ }^{1,2}$ \\ 1Klinika Neurochirurgii II Wydziału Lekarskiego, Warszawski Uniwersytet Medyczny \\ 2Klinika Neurochirurgii Instytutu Medycyny Doświadczalnej i Klinicznej PAN im. prof. M. Mossakowskiego, Warszawa
}

Neurologia i Neurochirurgia Polska 2012; 46, 4: 403-406

DOI: 10.5114/ninp.2012.30274

\section{Streszczenie}

W pracy przedstawiono dokonaną śródoperacyjnie modyfikację zastosowania i mocowania systemu Axon (Synthes) do stabilizacji potyliczno-szyjnej w szczególnej sytuacji klinicznej u chorego leczonego onkologicznie z powodu szpiczaka. Patologiczne złamanie, rozległość procesu oraz uszkodzenie zespolenia przedniego w odcinku szyjnym kręgosłupa spowodowało konieczność zastosowania stabilizacji potyliczno-szyjnej.

Stwierdzono odmienne warunki anatomiczne w obrębie łuski kości potylicznej w postaci jej ścieńczenia. Budowa kości uniemożliwiała zastosowanie mocowania za pomocą wprowadzanych śrub, dlatego dokonano modyfikacji mocowania za pomoca techniki opracowanej ad hoc (otwory trepanacyjne w łusce kości potylicznej i mocowanie drutem tytanowym). Omówiono modyfikacje i szczególne wskazania związane z przebiegiem klinicznym szpiczaka.

Słowa kluczowe: szpiczak, kręgosłup, stabilizacja potyliczno-szyjna, metoda operacyjna.

\section{Wstęp}

Szpiczak plazmocytowy (szpiczak mnogi) jest drugim co do częstości występowania nowotworem hematologicznym. Średni wiek zapadalności na szpiczaka to 65 lat.

\begin{abstract}
Intraoperative modification of use and stabilization of the Axon system (Synthes) for occipito-cervical fusion in a patient treated oncologically due to plasmocytoma is presented. Pathological fracture, range of the process and damage of anterior cervical fusion necessitated the use of occipito-cervical stabilization.

Different anatomical conditions within the occipital bone in the form of its thinning was observed. Fixing with screws was impossible due to the bone structure. In consequence, modification of stabilization with an ad hoc elaborated technique (burr holes in the occipital bone and stabilization with titanium wire) was implemented. Modifications and specific indications related to the clinical course of plasmocytoma are discussed.
\end{abstract}

Key words: plasmocytoma, spine, occipito-cervical fixation, operative technique.

Metodami leczenia szpiczaka w zależności od czasu wystąpienia objawów i wieku chorego są: autogenna transplantacja krwiotwórczych komórek macierzystych oraz kursy chemioterapii. Okres przeżycia chorego z rozpoznanym szpiczakiem wieloogniskowym wskutek prowa-

Adres do korespondencii: dr Jarosław Andrychowski, Klinika Neurochirurgii II Wydziału Lekarskiego, Warszawski Uniwersytet Medyczny, ul. Cegłowska 80, 01-809 Warszawa, tel./faks +48 2256904 90/22 83500 05, e-mail: j.andrychowski@wp.pl

Prace otrzymano: 22.07.2011; przyięto do druku: 9.01 .2012 
dzonego leczenia znacznie się wydłużył - przekracza nawet 62 miesiące (ponad 5 lat) - i zależy od postaci choroby (5 typów) oraz stadium zaawansowania [1-3].

$\mathrm{Na}$ okres przeżycia wpływa rozwój hematologicznych metod terapeutycznych oraz postępowanie chirurgiczne zapobiegające powikłaniom choroby w zakresie układu kostno-szkieletowego. W sytuacji złamania patologicznego kręgosłupa pacjentowi zagrażają powikłania neurologiczne mogące całkowicie ograniczyć jego funkcjonowanie i upośledzić komfort życia. W pracy przedstawiono przypadek pacjenta leczonego operacyjnie z powodu szpiczaka powodującego objawy neurologiczne z odcinka szyjnego kręgosłupa. Przedyskutowano postępowanie chirurgiczne, powikłania leczenia wynikające z przebiegu szpiczaka oraz dokonano oceny zmodyfikowanego zastosowania systemu stabilizującego w odcinku potyliczno-szyjnym.

\section{Opis przypadku}

Pacjent, 55 lat, został przyjęty do kliniki z powodu patologicznego złamania trzonu kręgu C 3 . Z uwagi na objawy neurologiczne (tetrapareza) i cechy ucisku na rdzeń kręgowy, stwierdzone w badaniu za pomocą rezonansu magnetycznego, mężczyznę leczono operacyjnie, wykonując $z$ dostępu przedniego usunięcie trzonu z naciekiem nowotworowym i odbarczenie rdzenia. W celu

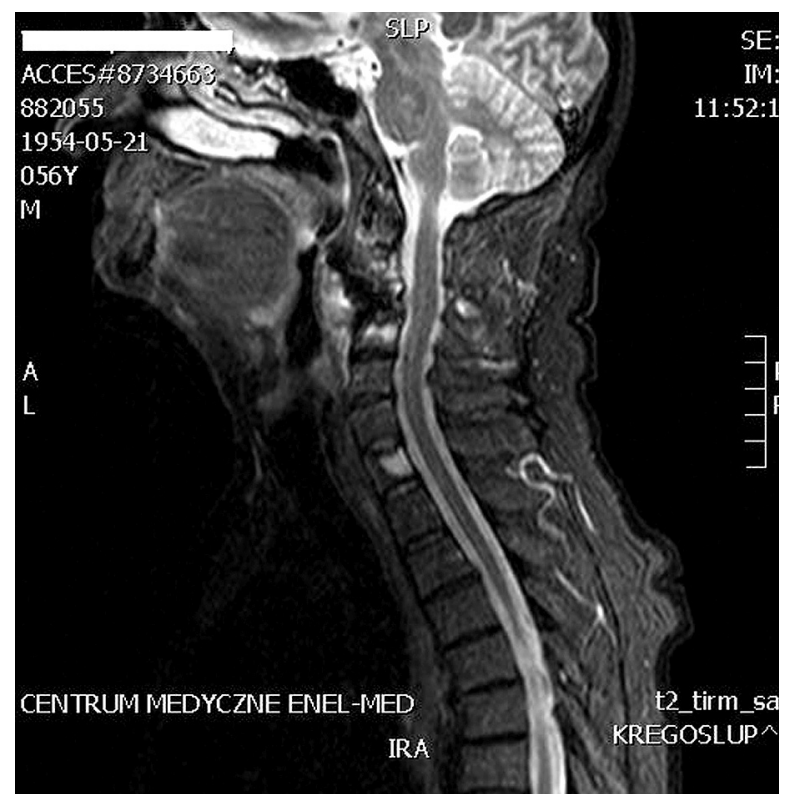

Ryc. 1. Badanie RM przed zabiegiem, widoczna destrukcja kolumny przedniej Fig. 1. MRl examination of cervical spine before surgery with anterior column destruction stabilizacji odcinka szyjnego kręgosłupa zastosowano protezę trzonu Synthes oraz płytę przednią Vectra na poziomie $\mathrm{C} 2-\mathrm{C} 4$, mocując śruby i płytę do prawidłowych trzonów. Objawy neurologiczne ustąpiły. Następnie pacjenta poddano kilku kursom chemioterapii i radioterapii. W czasie kontrolnej wizyty ambulatoryjnej stwierdzono prawidłowe funkcjonowanie pacjenta oraz brak objawów neurologicznych. Podczas kolejnej kontroli po 8 miesiącach od zabiegu chirurgicznego w wykonanym badaniu radiologicznym odcinka szyjnego kręgosłupa wykazano całkowite uszkodzenie zespolenia wskutek zniszczenia przez proces patologiczny masywu trzonu C2. Uwidocznionym w badaniu radiologicznym nieprawidłowościom nie towarzyszyły objawy neurologiczne o charakterze ubytkowym w zakresie kończyn. Obserwowano częściowe zniesienie ruchu obrotowego głowy i ból okolicy potylicznej.

Po przeprowadzeniu badań radiologicznych i ocenie kanału kręgowego (ryc. 1.) zdecydowano o wykonaniu u pacjenta stabilizacji szyjno-potylicznej z zastosowaniem systemu Axon z mocowaniem hakowym firmy Synthes. Przeprowadzono operację, modyfikując zakres i sposób zespolenia wynikający z toczącego się procesu patologicznego. Zrezygnowano z mocowania systemu śrubami do łuski potylicznej ze względu na brak możliwości prawidłowego wprowadzenia śrub. Stwierdzono wyraźne ścieńczenie kości w obrębie łuski potylicznej, nawet w jej przyśrodkowej części. Najkrótsze śruby ulegały wyrywaniu z miękkiej kości. Nie zastosowano śrub o większej długości z uwagi na ryzyko perforacji opon i móżdżku. Dwa pręty urządzenia stabilizującego przymocowano do łuski potylicznej poprzez nawiercenie symetrycznych otworów za pomocą frezu diamentowego, przez które przeciągnięto drut tytanowy (ryc. 2.). Unieruchomiono kompleks $\mathrm{C} 0-\mathrm{C} 1$ i znacznie wydłużono pręty do poziomu $\mathrm{C} 7$ oraz mocowanie zespolenia z użyciem haków ze względu na przebieg procesu patologicznego (ryc. 3. i 4.). U pacjenta występuje niestety całkowity brak ruchomości odcinka szyjnego kręgosłupa. Chory funkcjonuje bez objawów neurologicznych i jest pod opieką onkologiczną.

\section{Omówienie}

Zapewnienie komfortu życia i aktywności życiowej pacjentom $\mathrm{z}$ wieloogniskowym szpiczakiem, u których stwierdzono zmiany w obrębie trzonów kręgów, często związane z patologicznymi złamaniami, wymaga odpowiedniego postępowania przywracającego stabilność 
kręgosłupa. Leczenie operacyjne zapobiega powikłaniom neurologicznym w wyniku złamań patologicznych i pozwala na przedłużenie życia pacjenta z chorobą nowotworową [4-10].

W przedstawionym przypadku chorego leczono dwuetapowo. Pierwszy etap polegał na wykonaniu wertebrektomii i stabilizacji przedniej; niestety rozwój procesu i naciekanie trzonu $\mathrm{C} 2$ spowodowało uszkodzenie zespolenia. Konieczne stało się wykonanie stabilizacji potyliczno-szyjnej. Pacjent nie zgłaszał zaburzeń połykania, dlatego nie decydowano się na postępowanie drogą dostępu przedniego i usuwanie uszkodzonego zespolenia. Zastosowany w wieloogniskowym szpiczaku system stabilizacji szyjno-potylicznej wymagał modyfikacji. Na krytyczną ocenę zasługuje sposób mocowania prętów zespolenia do łuski kości potylicznej. Śruby polecane przez producenta nie dają stabilnego mocowania prętów do łuski kości potylicznej z uwagi na możliwe zmiany struktury i gęstości kości w przebiegu szpiczaka. Przedoperacyjne badanie radiologiczne nie uwidoczniło ognisk osteolizy w obrębie łuski potylicznej, których obecność spowodowałaby zmianę kwalifikacji.

Określenie długości śrub mocujących w prawidłowych warunkach anatomicznych jest związane $z$ budową łuski kości potylicznej i jej zmienną grubością, co podkreślają inni autorzy [11-15]. Należy zwrócić uwagę, że stosowanie w prawidłowych warunkach śrub zbyt krótkich może spowodować ich wyrwanie, a przekroczenie grubości kości i opony może spowodować powikłanie w postaci płynotoku czy uszkodzenia móżdżku.

W szpiczaku istnieją szczególne warunki - z uwagi na strukturalną przebudowę kości spowodowaną wzrostem osteoklastogenezy i jednoczesnym spowolnieniem osteoblastogenezy [16-19]. Musi to być uwzględniane w przypadku wykonywania zabiegów stabilizujących związanych z zastosowaniem i mocowaniem implantów w tkance kostnej. Łuska kości potylicznej w prezentowanym przypadku miała niewielką grubość, a śródoperacyjnie stwierdzono cechy przebudowy kostnej, stąd niemożność zastosowania zespolenia za pomocą śrub.

W przypadku szpiczaka zawsze trzeba wziąć pod uwagę możliwe zmiany struktury kostnej łuski potylicznej czaszki i rozważyć zaproponowaną technikę mocowania prętów, co pozwoli zapobiec niepotrzebnym powikłaniom. W każdym przypadku przeprowadzania stabilizacji potyliczno-szyjnej wskazana jest radiologiczna przedoperacyjna ocena grubości łuski kości potylicznej. Modyfikacją stabilizacji złamanego segmentu C2 w przebiegu szpiczaka jest zastosowanie odpowiednio wydłużonego mocowania zespolenia do kręgów w odcinku szyjnym.

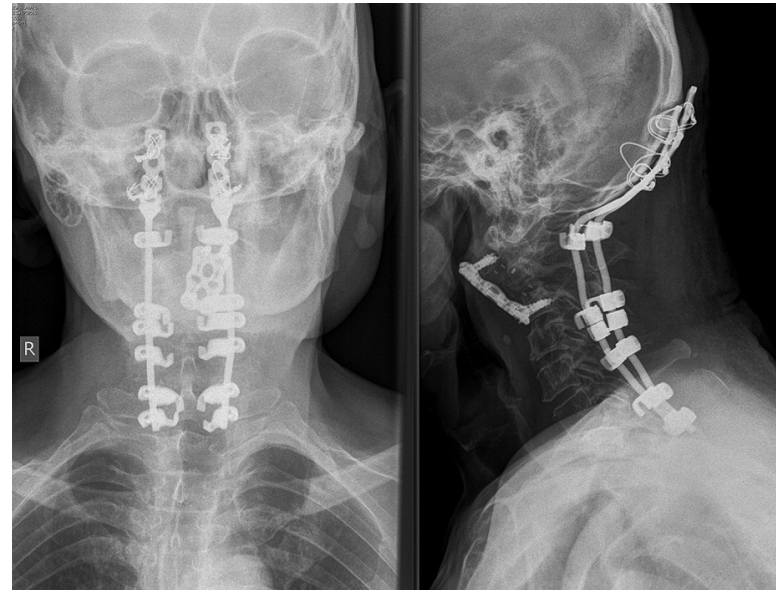

Ryc. 2. Badanie kontrolne RTG po wykonanej stabilizacii tylnej

Fig. 2. X-ray control examination after posterior stabilisation

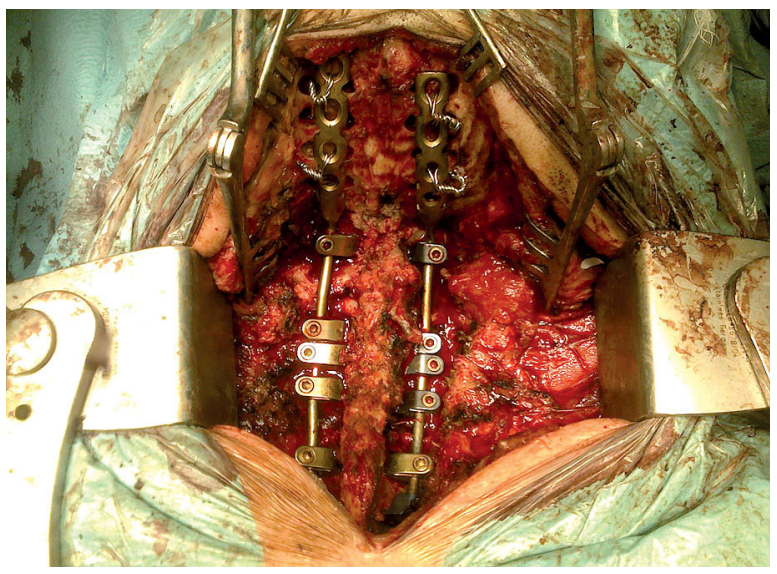

Ryc. 3. Widok śródoperacyiny stabilizacii potylizzno-szyjnej

Fig. 3. Intraoperative view of occipito-cervical stabilisation

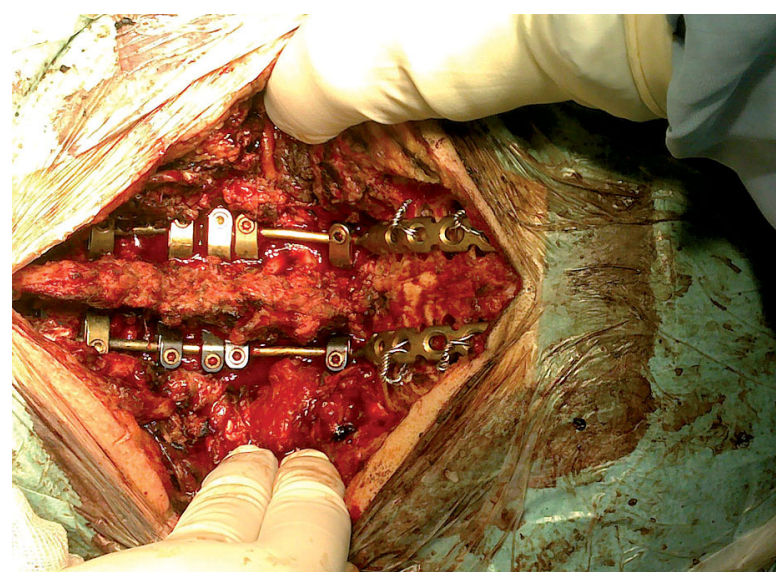

Ryc. 4. Ostateczny widok stabilizacii potyliczno-szyinej po umocowaniu elementów

Fig. 4. Finally view of posterior instrumentation after fixation 
Wiąże się to z przewidywanymi zmianami wytrzymałości tkanki kostnej w przebiegu szpiczaka i dlatego zespolenie musi być przytwierdzone na dłuższym odcinku kręgosłupa szyjnego.

\section{Oświadczenie}

Autorzy zgłaszają brak konfliktu interesów.

\section{Piśmiennictwo}

1. Dmoszyńska A. Postępy w diagnostyce i leczeniu szpiczaka plazmocytowego. Onkol Prakt Klin 2007; 3: 69-76.

2. Garban F., Attal M., Michallet M. i wsp. Prospective comparison of autologous stem cell transplantation followed by dosereduced allograft (IFM 99-03 trial) with tandem autologous stem cells transplantation (IFM 99 -04 trial) in high risk do novo multiple myeloma. Blood 2006; 107: 3474-3484.

3. Dmoszyńska A. Terapie celowane w szpiczaku plazmocytowym. Acta Haemat Pol 2005; 36: 52-58.

4. Crockard H.A., Sonntag V.K.H. Upper cervical and occipital arthrodesis. W: Benzel E.C. [red.]. Spine surgery: techniques, complication avoidance and management. Churchill Livingstone, New York 1999, ss. 207-218.

5. Paquis P., Breuil V., Lonjon M. i wsp. Occipitocervical fixation using hooks and screws for upper cervical instability. Neurosurgery 1999; 44: 324-331.

6. Perin N.I., Baldwin N.G., Coper P.R. High cervical and occipitocervical plate, rod, wire and bone techniques. W: Benzel E.C. [red.]. Spine surgery: techniques, complication avoidance and management. Churchill Livingstone, New York 1999, ss. 10091016.

7. Salas E., Sekhar L.N., Zyial I.M. i wsp. Variations of the extremelateral craniocervical approach: anatomical study and clinical analysis of 69 patients. J Neurosurg (Spine) 1999; 90: 206-219.

8. Viale F.L., Oliver M., Cahill D.W. Rigid occipitocervical fusion. J Neurosurg (Spine) 1999; 91: 144-150.

9. Pait T.G., Al-Mefty O., Boop F.A. i wsp. Inside-outside technique for posterior occipitocervical spine instrumentation and stabilization: preliminary results. J Neurosurg (Spine) 1999; 90: 1-7.

10. Jackson R.J., Gokaslan Z.L. Occipitocervicothoracic fixation for spinal instability in patients with neoplastic processes. $J$ Neurosurg (Spine) 1999; 91: 81-89.

11. Maciejczak A., Radek A., Zapałowicz K. i wsp. Metody stabilizacji pogranicza czaszkowo-kręgosłupowego - kryteria doboru. Neurol Neurochir Pol 1999; 33: 1151-1163.

12. Radek A., Zapałowicz K., Maciejczak A. i wsp. Przypadek poważnej dyslokacji pogranicza czaszkowo-kręgosłupowego na tle reumatoidalnego zapalenia stawów. Neurol Neurochir Pol 2000; 34: 187-196.

13. Maciejczak A., Radek A. Stabilizacja pogranicza czaszkowo-kręgosłupowego śrubami. Neurol Neurochir Pol 1999; 33: $1403-$ 1413.
14. Radek A. Komentarz do pracy: Maliszewski M., Ładziński P., Majchrzak H. Stabilizacja szyjno-potyliczna w chirurgicznym leczeniu patologii pogranicza czaszkowo-kręgosłupowego. Neurol Neurochir Pol 2005; 39: 195.

15. Maliszewski M., Ładziński P., Majchrzak H. Stabilizacja szyjno-potyliczna w chirurgicznym leczeniu patologii pogranicza czaszkowo-kręgosłupowego. Neurol Neurochir Pol 2005; 39 : 188-194.

16. Yaccoby S. Advances in the understanding of myeloma bone disease and tumour growth. Br J Haematol 2010; 149: 311-321.

17. Roodman G.D. Osteoblast function in myeloma. Bone 2011; 48: 135-140.

18. Vallet S., Raje N. Bone anabolic agents for the treatment of multiple myeloma. Cancer Microenviron 2011; 4: 339-349.

19. Vallet S., Raje N. Osteoclast activation in multiple myeloma. Curr Clin Oncol 2010; 28: 183-198. 